\title{
DOES ANYONE CARE ABOUT SUPPORT INSIDE THE UNIVERSITY? THE MEDIATING ROLE OF PERCEIVED ORGANISATIONAL SUPPORT
}

\author{
Luen-Peng Tan \\ Universiti Tunku Abdul Rahman \\ Yuen-Onn Choong* \\ Universiti Tunku Abdul Rahman \\ Kum-Lung Choe \\ Universiti Tunku Abdul Rahman
}

\begin{abstract}
Social exchange theory evokes the maximization of one's personal interests or benefits when one is engaging in a relationship. The central tenant of social exchange theory focuses on the notion of reciprocity. Perceived organizational support (POS) should elicit the norm of reciprocity and employees would feel they are obligated to help organizations to achieve goals. The main objective of this study is to examine the mediating effect of POS between organizational justice and supervisory support with affective commitment. More precisely, five hypotheses were tested using a sample of 207 academics of Malaysian private universities. Partial least squares path modeling was utilised to assess the measurement and structural model. In this study, organizational justice is envisaged as a multi-dimensional construct which comprises distinct variables namely - procedural justice, distributive justice and interactional justice. Supervisory support and affective commitment are unidimensional constructs. POS was found to be a mediator for the relationship between organizational justice and supervisory support with affective commitment. The findings of this study were expected to shed light on the scant literature of POS especially its mediating role for the relationship between organizational justice, supervisory support, and affective commitment.
\end{abstract}

Keywords: Perceived organizational support; Affective commitment; Organizational justice; Supervisory support, private universities.

Received: 18 August 2018

Accepted: 20 May 2020

\section{INTRODUCTION}

Globalization has altered the landscape of today's universities around the world and it is becoming more intensified due to the sheer numbers of institutions and people involved. In most countries, higher education has become a large and complex enterprise. Indeed, universities are being considered as the engines of a knowledge-based economy, as a complex, large and growing enterprise employing thousands of people to work. Besides, the Malaysian government also

\footnotetext{
- Corresponding author: Faculty of Business and Finance, Universiti Tunku Abdul Rahman, Jalan Universiti, Bandar Barat, 31900 Kampar, Perak, Malaysia, (605) 4688888 and choongyo@utar.edu.my
} 
anticipates that higher education will play a vital role in nation building especially in the economic and social development. Education is perceived as an important social force which intertwines with the country's economic and political development process. Transforming Malaysia into a knowledge-based economy requires the aids from the higher education to provide skilled and knowledgeable work force to build the nation's competitiveness in the region as well as in the global arena.

Malaysian government also acknowledges the importance of private higher institutions in providing the required skills and knowledge to the people in building the nation to achieve the vision of the country. The government has been actively supporting private higher education since 1995 to develop their own unique and innovative education programs. The government support is essential and necessary due to the structural transformation of the country's economy, and the emphasis of the educational policy to build a pool of well-educated and skilled professional (Chen \& Su-Yen, 2016).

The government efforts in developing the nation's higher educational institutions to a higher level and become more competitive in the international arena are undeniable. However, the micro-level aspects of employees of the higher educational institutions should be also paid attention. For instance, Malaysian universities are facing high turnover rate of academics particularly in Private Higher Education Institutes (PHEIs). The turnover rate among educators was at 29 percent (Rathakrishnam, Imm \& Kok, 2016). Such phenomenon will eventually create negative effects to the university in the replacement costs and work disruption (Lew, 2009). Furthermore, Malaysian universities are setting higher goals and objectives to improve the universities' standards in various aspects. Academics are also confused on how to balance up their energy, focus and time between the responsibilities of teaching, research, publishing, supervision, community services, consultancy, administration and other tasks. In addition, academics are also wondering on how to socialize themselves in a "bureaucratic" organizational culture (Wahat, Nasi \& Omar, 2009). Making the thing worse, local universities continue to face the problem of academic turnover. Academics decide to leave educational industry for other industries with different purposes.

As highlighted in Ramli, Salahudin, Sainol and Suandi (2014), the liberalization, deregulation and privatization of higher learning institution which has caused academics suffered with the limitation of capacity and capability as compared to public higher learning institution. In order for university to achieve better ranking in both international and national level, academics are not only expecting to do publication, research, postgraduate supervision, teaching in both undergraduate and postgraduate level and consultancy, but also required to deliver duties such as community services, marketing and administrative work (Azman, Amy, Elizabeth, Kong \& Ju, 2010). Hence, this has caused to high turnover intention and commitment issues (Rathakrishnam et al., 2016). From a long term perspective, the nation's dream to develop quality human capital and workforce will also be jeopardized by such phenomenon.

One caveat to be noted perceived organizational support (POS) is playing an important role in any organization regardless of private organization or public organization (Ding \& Shen, 2017; Ahmed \& Nawaz, 2015; Madden, Mathias \& Madden, 2015; Stinglhamber, Marique, Caesens, Hanin \& Zanet, 2015). It is critical for employees to receive supports from organization and their coworkers when performing their jobs as this indicates that the management of organization value their work efforts and care about their well-being. Eventually, this would increase the commitment to their 
respective organization and reduce the intention to leave (Madden et al., 2015). It is apparent that organizational justice and supervisory support are the important constructs for higher education research. However, there is still lack of studies conducted on the relationship between organizational justice and POS. Moreover, supervisory support is envisaged as a salient antecedent to predict POS. According to Levinson (1965) supervisors act as organizational agents and they frequently evaluate the performance of the subordinates. Besides, supervisors are also responsible for communicating the organizational goals with employees. This study hopes to contribute to POS literature by examining the relationship between organizational justice and POS, supervisor support and POS as well as POS and affective commitment. Additionally, this study also encapsulates the examination of POS as a mediating variable on the speculated relationships. Additionally, we posit that through interactions with superiors, academics would perceive that there is a certain level of fairness preponderant their perceptions that university does care about their well fair and in due course would engender collective effect on POS. Likewise, delineating from the notion of reciprocity norm, superiors would exhibit supportive behaviors on academic members emphasizing on socioemotional guise eventually influence their commitment to university affectively.

In the past, there are studies tested and confirmed the relationship between organizational justice and POS (Lee, Yusof, Geok \& Omar, 2017) in the context of Malaysian high performance school as well as the relationship between supervisory support and POS (Purang, 2011) in service sector. Apart from this, Jais and Mohamad (2017) also examined the relationship between POS and organizational commitment among academics in Malaysian universities. Purang (2011) also argued that POS is able to mediate the relationship between supervisory support and organizational commitment. However, to the best of our knowledge, there is no study tested the mediating effect of POS on the relationship between organizational justice and affective commitment as well as relationship between supervisory support and affective commitment. Addition to this, this study could provide some useful insight to Malaysian universities as well as Ministry of Education on how to enhance academics commitment and reducing their intention to leave through providing a sufficient support from organization as well as immediate supervisor.

\section{LITERATURE REVIEW}

\subsection{Organizational Justice and Perceived Organizational Support}

Employees evaluate fairness received from organizations through the lenses of procedural and distributive justice (Greenberg, 1990). Distributive justice refers to the perceived fairness of outcome (Cropanzano, Prehar \& Chen, 2002). Meanwhile procedural justice refers to the fairness of the process by which a decision is made (Konovsky, 2000). As for social guise of procedural justice namely interactional justice, involved the quality of interpersonal treatment in resource allocation. Shore and Shore (1995) contended that when employees received fair treatment repeatedly, this would generate cumulative effect on POS indicating concern exerted by organizations on employees' welfare. Moreover, they further postulated that procedural justice have a stronger influence on POS than distributive justice. Furthermore, Rhoades and Eisenberger (2002) revealed that procedural justice predicts POS by stating that when employees' opinions were being heard and treated with dignity, it would create strong impression that the organization values one's contribution and cares about his/her well-being. 
H1: Organizational justice is positively related to perceived organizational support

\subsection{Supervisor Support and Perceived Organizational Support}

Supervisors are considered to be the agents of organization have direct dealings with employees. Such phenomenon would eventually contribute to employees' association of supervisor support with POS. There is a positive relationship between supervisor support and POS when employees believe that they are being supported by their supervisors (Rhoades, Eisenberger \& Armeli, 2001). Moreover, Eisenberger, Stinglhamber, Vandenberghe, Sucharski and Rhoades (2002) conducted a longitudinal study of supervisor support with POS found that perceived organizational support changed in response to changes in perceived supervisor support indicating that supervisor support is an antecedent to POS. However, to date, we notice that there is still limited empirical study conducted on the relationship between supervisor support and POS. Hence, it has transpired us to conduct this study to empirically examine the relationship between these two dimensions in hopes to contribute to the scant of empirical evidence specifically in the Malaysian context.

\section{$\mathrm{H} 2$ : Supervisor support is positively related to perceived organizational support}

\subsection{Perceived Organizational Support and Affective Commitment}

Perceived organizational support is a salient construct which indicates the extent to which employees believe that their organization values their contributions and cares about their wellbeing (Eisenberger, Huntington, Hutchison \& Sowa, 1986). POS is envisaged as a key predictor of affective commitment (Eisenberger et al., 1986). These two constructs are conceptually and empirically distinct from each other although these constructs concentrates on the connection between an individual employee and the organization (Bishop, Scott, Goldsby, \& Cropanzano, 2005). Affective commitment represents the employee's attachment to and identification with an organization. Individuals with a high level of affective commitment continue to work for an organization because they want to (Aubé, Rousseau, \& Morin, 2007). On the other hand, POS is the extent to which the organization values their contributions and cares about their well-beings (Shore \& Tetrick, 1991).

H3: Perceived organizational support is positively related to affective commitment

\subsection{Perceived Organizational Support as a Mediator}

Organizational researchers utilize social exchange theory as an influential framework to explain work behavior (Cropanzano \& Mitchell, 2005). The relationship between POS and affective commitment has been explained from the spectrum of social exchange (Lee \& Peccei, 2007). The centrality of social exchange theory focuses on maximizing individual's own personal benefits or interests when entering into relationships with others (Blau, 1964). Personal resources (information or money) are exchanged between partners without concerning the identity of the senders. Resources could be in other forms such as communication of caring or respect. As pointed out by Aselage and Eisenberger (2003) social exchange theory highlights the importance to understand employees' motivation to assist organization to achieve its goals. Such objective can be only achieved when there is a mutual obligation between employees and employers. The ideology of exchange can be delineated from the norm of reciprocity whereby people should help those who 
helped them (Gouldner, 1960). Deriving from the notion of reciprocity, this study therefore contends that supervisor support should be related to POS as employees may return the favors received from the supports of supervisors through greater work performances. On the other hand, when employees perceived that they have been justly treated by the organization, employees may form their perceptions of the organization as being supportive. Therefore, it is postulated that there is a relationship between justice and POS. With regard to affective commitment, employees develop favorable attitudes and behavior consistent with POS as a mean to maintain or balance relationship with organization. The scant empirical evidence examining the mediating role of POS between justice and supervisor support with affective commitment in the literature has transpired this study to empirically examine the mediating role of POS in relation with the theory of social exchange.

H4: Perceived organizational support mediates the relationship between organizational justice and affective commitment

H5: Perceived organizational support mediates the relationship between supervisory support and affective commitment.

\subsection{Conceptual Framework}

Based on the above literature discussion, a proposed conceptual framework is formulated and proposed in Figure 1. According to social exchange theory, reciprocity is envisaged as a paramount element in close relationship (Gouldner, 1960). Unlike in economic exchange, when individual is engaging a quality social exchange relationship often demand less immediate payback and are more generous. With long period of time, individuals develop mutual and beneficial exchanges tend to move from economic exchange to social exchange as a mean to reciprocate to develop trust, loyalty, and commitment (Mitchell et al., 2012). From the organizational perspective, reciprocity norm is utilized both by employer and employee in their relationship, favorable treatment received by either party is reciprocated eventually leads to desired and beneficial outcomes for both parties (Rhoades \& Eisenberger, 2002). Therefore, it is posited that organizational justice and supervisory support are significantly related to POS. This has supported by Lee et al., (2017) and Purang (2011) where when an individual perceived fairness as well as support from immediate supervisor, he or she would tend to perceive this as a kind of support from their organisation. Similarly, Purang (2011) also further argued that when an individual perceived support from organization, he or she would tend to engage themselves to the organization affectively. Therefore, the research framework is constructed where we propose that POS will mediate the relationship between organizational justice and affective commitment as well as between supervisory support and affective commitment among academics from private universities.

Figure 1: Proposed Conceptual Framework

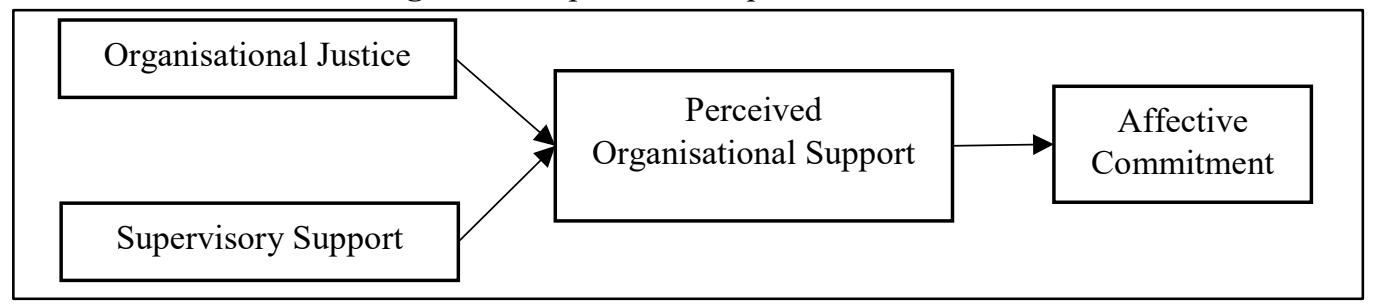




\section{METHODOLOGY}

Stratified sampling technique was adopted to select the samples from sampling frame. The sampling frame consists of approximately 6,000 faculty members ranging from tutor to senior professor from top four private universities in Malaysia. These four private universities are actively participating in various ranking and ranked consistently in the past two years (2016 and 2017) in both international and national levels. Apart from this, academics from these private universities have a common job scope where they are required to do research and publication, postgraduate supervision, teaching in both undergraduate level and postgraduate level, consultancy services, administrative works and community services. A total of 500 set of questionnaires were distributed to academics. However, only 207 usable questionnaires were returned which yielded a response rate of $41.4 \%$. In order to achieve worthwhile results, at least 76 samples should be selected at the significance level of 0.05 and effect size at 0.15 (Green, 1991). Of the 207 respondents, $45 \%$ are female and 55\% are male. In terms of race sample distribution, $87(42 \%)$ respondents are Malay, 79 (38\%) Chinese respondents, 37 (18\%) Indian respondents and $4(2 \%)$ are foreigners. For age, 59 respondents fall under age ranged from 30 years and below (29\%), 90 respondents fall under 31 to 40 years $(43 \%), 35$ in the range of 41 to 50 years $(17 \%)$ as well as 23 respondents with more than 50 years old $(11 \%)$.

The measurement of affective commitment was adapted from Allen and Meyer (1990) which consists of six items. An abbreviated 8-item scale of POS-8 was adopted from the widely used 36item perceived organizational support survey (SPOS) (Eisenberger et al., 1986). This version of SPOS is most simplified and shortest instrument derived from the original version of SPOS. POS8 comprises 8 statements which are equally phrased in both positive and negative terms. Supervisory support was measured on a four-item scale developed by Rhoades et al. (2001). For the construct of organizational justice, the 20 -items measurement constructed by various researchers and whereby organizational justice comprises of three higher order constructs namely - procedural justice, distributive justice and interactional justice. Procedural justice with six-items was developed by Price and Mueller (1986) while, distributive justice consists of five-items was adopted from Niehoff and Moorman (1993). Interactional justice comprises nine-items was constructed by Bies and Moag (1986) as well as Shapiro, Buttner and Barry (1994).

\section{RESULTS AND DISCUSSION}

\subsection{Results}

The partial least square path modeling approach or variance based approach was adopted by using SmartPLS software to estimate the parameters in both the outer model and the inner model. For construct validity, the outer loadings for each item are above 0.7 except for item 4 of Supervisory Support. The outer loadings for the item fall in between 0.4 and 0.7 could be retained, provided that the AVE of the particular construct achieved the minimum cutoff value of 0.5 (Hair, Hult, Ringle \& Sarstedt, 2017). Since, the AVE for supervisory support is less than 0.5 , it is suggested to remove the item (SS4) in order to improve the AVE for supervisory support. The AVE for each latent construct has fulfilled the threshold value of 0.5 specified by (Hair et al., 2017). The AVE for latent constructs fall in between 0.517 to 0.909. Succinctly, the AVE for each construct indicated that all indicators within each construct explain more than half of the variance (Hair, 
Sarstedt, Hopkins \& Kuppelwieser, 2014). For the composite reliability, each construct has exceeded the recommended value of 0.7 (Chin, 2010) which meets adequate convergent validity. For the discriminant validity, the square root of AVE for each construct indicates the highest value among the correlation value in the same column. Apart from this, the indicator loadings of measures construct is at least 0.10 larger than cross loadings in the same row and column (Hair et al., 2017). In view of the results, this is verified that and confirmed that there is adequate discriminant validity in this measurement model.

For structural model analysis, at first, the predictive power of the endogenous construct: perceived organizational support with R2 value of 0.5498 and affective commitment with R2 value of 0.4223 (Table 1 and Figure 2). Based on Cohen's guideline, both endogenous predictive powers are considered substantial where the values exceeded the threshold value of substantial level at 0.26 (Cohen, 1988). It is posited that organizational justice $(\beta=0.519, \mathrm{p}<0.01)$ and supervisory support $(\beta=0.257, \mathrm{p}<0.05)$ are significantly related to perceived organizational support. Hence, this implied that hypotheses 1 and 2 are statistically supported. Perceived organizational support $(\beta=0.650$, $\mathrm{p}<0.01$ ) is found to be significantly related to affective commitment. Thus, the proposed hypothesis 3 is supported. It is also important and advisable to assess the effect size of each hypothesized relationship. The effect size for the relationship between organizational justice and perceived organizational support is 0.208 whereby the effect size of 0.208 exceeded the suggested cutoff value for medium level at 0.15 . For the relationship between supervisory support and perceived organizational support, the effect size of 0.052 exceeded the threshold value of small level at 0.02 (Cohen, 1988). In view of the predictive relevance results, it is revealed that the $\mathrm{H} 2$ ranging from 0.336 to 0.594 as well as F2 ranging from 0.277 to 0.286 . All values are positive and have also achieved the minimum value of large level at 0.35 which means that the proposed model has an acceptable and adequate predictive relevance (Henseler, Ringle \& Sinkovics, 2009). The average communality and average R2 is 0.465 and 0.486 respectively. Subsequently, the average communality multiplies with average R2 and square root the value so as to obtain Goodness of Fit $(\mathrm{GoF})$ value of the model. The GoF value of 0.475 greater than the threshold value of large GoF level at 0.36 .

Table 1: Structural Model Results

\begin{tabular}{|c|c|c|c|c|c|c|c|c|c|}
\hline \multirow{2}{*}{ H } & \multirow{2}{*}{ Path } & \multirow{2}{*}{ Beta } & \multirow{2}{*}{$\begin{array}{l}\text { Standard } \\
\text { Error }\end{array}$} & \multirow{2}{*}{$\begin{array}{c}\mathbf{t}- \\
\text { Statistics }\end{array}$} & \multirow{2}{*}{ Results } & \multicolumn{2}{|c|}{$\mathbf{Q}^{2}$} & \multirow{2}{*}{$\mathbf{f}^{2}$} & \multirow{2}{*}{$\mathbf{R}^{2}$} \\
\hline & & & & & & $H^{2}$ & $F^{2}$ & & \\
\hline H1 & $\mathrm{OJ}>\mathrm{POS}$ & 0.519 & 0.075 & 5.373 & Supported & \multirow{2}{*}{0.594} & \multirow{2}{*}{0.277} & 0.208 & \multirow{2}{*}{0.55} \\
\hline $\mathrm{H} 2$ & $\mathrm{SS}>\mathrm{POS}$ & 0.257 & 0.095 & 2.697 & Supported & & & 0.052 & \\
\hline $\mathrm{H} 3$ & $\mathrm{POS}>\mathrm{AC}$ & 0.650 & 0.039 & 16.882 & Supported & 0.336 & 0.286 & N/A & 0.422 \\
\hline
\end{tabular}

Note: $\mathrm{Q}^{2}=$ Predictive Relevance, $\mathrm{H}^{2}=$ Communalities, $\mathrm{F}^{2}=$ Redundancies, $\mathrm{f}^{2}=$ Effect Size, $\mathrm{R}^{2}=$ Explanatory Power, $\mathrm{OJ}=$ Organisational Justice, $\mathrm{POS}=$ Perceived Organisational Support, $\mathrm{SS}=$ Supervisory Support, AC=Affective Commitment

For mediation analysis (Table 2 and Figure 2), it is evident that perceived organizational support mediated the relationships between organizational justice and affective commitment $(t=5.271)$ as well as supervisory support and affective commitment $(t=2.531)$. Hence, hypotheses 4 and 5 are supported. 
Table 2. Mediation Analysis

\begin{tabular}{|c|c|c|c|c|c|c|c|c|}
\hline \multirow[t]{2}{*}{$\mathbf{H}$} & \multirow[t]{2}{*}{ Path } & \multirow{2}{*}{$\begin{array}{l}\text { Path } \\
\mathbf{a}\end{array}$} & \multirow{2}{*}{$\begin{array}{c}\text { Path } \\
\text { b }\end{array}$} & \multirow{2}{*}{$\begin{array}{l}\text { Indirect } \\
\text { Effect }\end{array}$} & \multirow{2}{*}{$\begin{array}{c}\text { Standard } \\
\text { Error }\end{array}$} & \multirow[t]{2}{*}{ t-value } & \multicolumn{2}{|c|}{$\begin{array}{c}\text { Bootstrapped } \\
\text { Confidence Interval }\end{array}$} \\
\hline & & & & & & & 95\% LL & $95 \%$ UL \\
\hline $\mathrm{H} 1$ & $\mathrm{OJ}>\mathrm{POS}>\mathrm{AC}$ & 0.519 & 0.650 & 0.337 & 0.064 & 5.271 & 0.212 & 0.463 \\
\hline $\mathrm{H} 2$ & $\mathrm{SS}>\mathrm{POS}>\mathrm{AC}$ & 0.257 & 0.650 & 0.167 & 0.066 & 2.531 & 0.038 & 0.296 \\
\hline
\end{tabular}

Note: OJ=Organisational Justice, POS=Perceived Organisational Support, SS=Supervisory Support, AC=Affective Commitment

Figure 2: Path Modelling

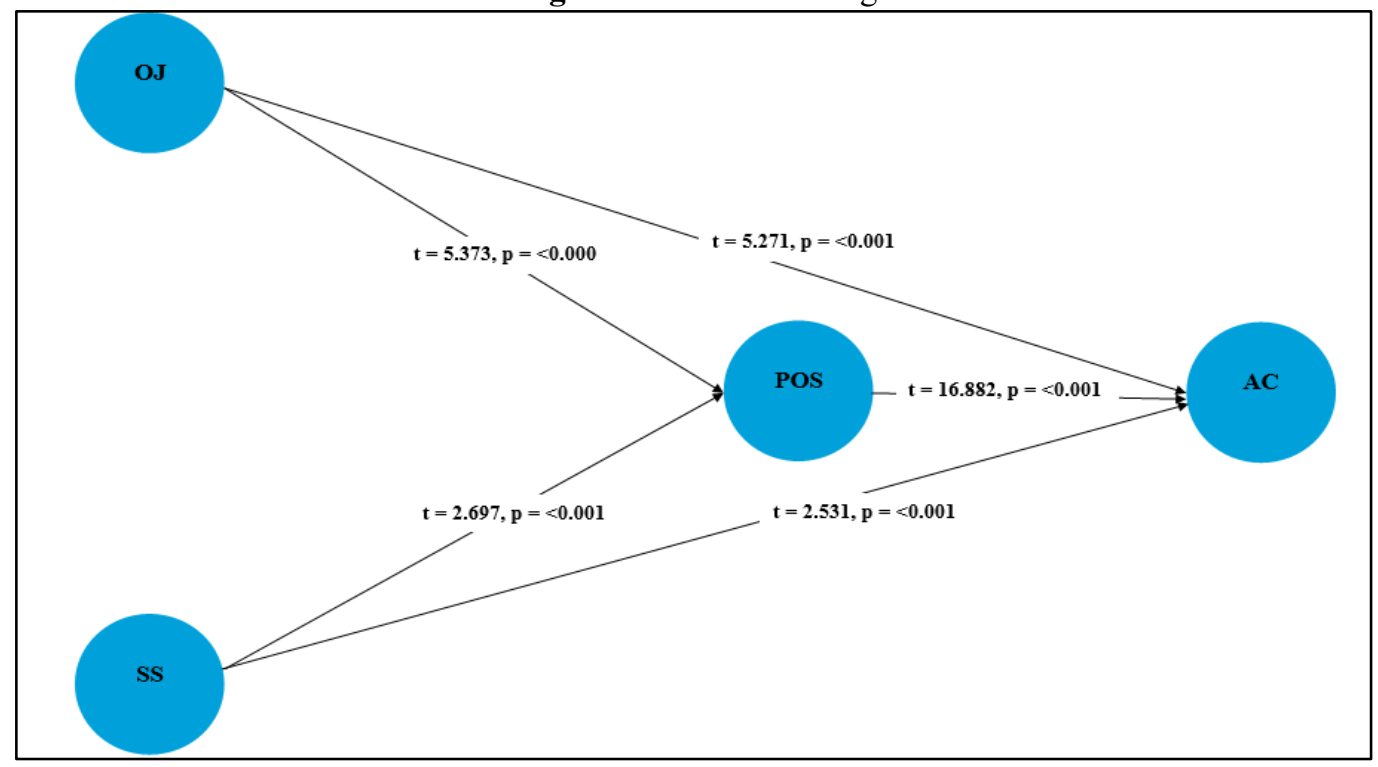

\subsection{Discussion}

The purpose of this study was to examine the relationships of organizational justice and supervisory support with POS. The results of this study reveal that organizational justice and supervisory support are found significantly related with perceived organizational support, this finding is consistent with empirical evidences in Shore and Shore (1995), Yang and Zhang (2012), Dawley, Andrews and Bucklew (2008) as well as Rhoades and Eisenberger (2002). When employees constantly and repeatedly receive fair or impartial treatments from the immediate superior, employees would associate such treatments of fairness in decision pertaining resource distribution should have strong cumulative effect on POS indicating concern exerted by organizations on employees' welfare (Shore \& Shore, 1995). Thus, hypothesis (H1) confirms that there is a positive relationship between organizational justice and POS. As for the relationship between supervisory support and POS, results of this study reveal that the relationship between supervisor support and POS is positively related indicating that academics generally perceived that their superiors were very supportive, value and cares about their well-being and this should directly relate to POS 
(Eisenberger et al., 2002). Therefore, hypothesis (H2) is supported indicating the relationship between supervisory support and POS is positive. Concerning the third hypothesized relationship, the statistical outcome of this study demonstrates the relationship between POS and affective commitment is positively related. This result is in line with the findings of Caesens, Marique and Stinglhamber (2014), Bilgin and Demirer (2012) and Marique, Stinglhamber, Desmette, Caesens and Zanet (2012). Moreover, Lee and Peccei (2007) contended that social exchange theory is able to explain the nature of the relationship between POS and organizational commitment.

Furthermore, we also examined if POS mediate the relationships of organizational justice and supervisory support with affective commitment. Result of this study reveals that POS mediates the relationship between organizational justice and affective commitment as well as the relationship between supervisory support and affective commitment. As mentioned in literature review, the ideology of exchange can be delineated from the norm of reciprocity whereby people should help those who helped them (Gouldner, 1960). If employee receives sufficient support and guidance from their supervisors, then he or she would perceive the sense of organizational support (Choong, Tan \& Choe, 2014). Eventually, he or she would affectively commit to their jobs as well as organization (Caesens et al., 2014). Similarly, if an individual perceived that he or she is being treated fairly by the employer, he or she would associate such treatment as a form of support from the organization (Yang \& Zhang, 2012). Subsequently, this would further encourage individuals to commit to their works by contributing substantial efforts in their jobs and organization affectively. Future research should rely on longitudinal design to examine the evolution of POS in relation with other relevant dependent variables. Albeit other possible relevant dimensions are not tested, we suggest that university's management should concentrate the guises of organizational justice and supervisory support as means of communication on how university appreciates, values and supports its academics.

\section{CONCLUSION}

This study has implications for practice. First, the management of private universities should instill the element of fairness into their operation system. Universities' management should be fair when it comes to equally treating academics. At operational level, superiors with supportive behavior are more likely to create positive work relationships by instilling a collective sense of support and commitment among academics. Superiors should be trained on how to be fair and impartial when allocating academics' workloads; evaluating performance; distribution of administrative works. More generally, universities should recognize that to be effective, cultivating culture of fairness at operational level is pivotal to foster positive working attitudes among academics.

This study also illustrates that superiors with strong support behaviors enabling the generation of perceptions of support among academics. When academics perceived that their superiors are supportive, they are committed to their works affectively. Albeit this finding is limited to a specific industry (i.e. private universities), continuous supports from superior are undeniably paramount indicating academics generally think that the superiors appreciate and value their work efforts. Thus, superiors are advised to effectively communicate with academics in order to help the university to achieve its goals. Superiors are also advised to exert the feeling of cares with the academics. Consistent exertion of cares by superiors may give the sense of protection to academics 
whereby superiors are not only concern about the problems academics face with their works but also their personal or family lives.

Effective management requires organizations to exert the sense that organizations' actions are motivated by good intentions. Our findings reveal that when academics perceive that the university is supportive, it would ultimately lead to academics' affective commitment. It is advised that management of university should not only just inform of its actions and intentions only but to pay more attentions and closely monitor on the reactions of academics by involving them to participate in major decisions which ultimately affect their well-beings. Proactive communication adoption is crucial between superiors and academics in helping to maintain levels of workforce commitment especially during the juncture of intense competitions in this industry nowadays.

\section{REFERENCES}

Ahmed, I., \& Nawaz, M. M. (2015). Antecedents and outcomes of perceived organizational support: A literature survey approach. Journal of Management Development, 34(7), 867-880.

Allen, N. J., \& Meyer, J. P. (1990). The measurement and antecedents of affective, continuance and normative commitment to the organization. Journal of Occupational Psychology, 63(1), 1-18.

Aselage, J., \& Eisenberger, R. (2003). Perceived organizational support and psychological contracts: A theoretical integration. Journal of Behaviour, 24(5), 491-509.

Azman, I., Amy, Y., Elizabeth, Y., Kong, L. K., \& Ju, S. Y. (2010). Occupational stress features, emotional intelligence and job satisfaction: An empirical study in private institutions of higher learning. Negotium, 16(5), 5-33.

Bies, R. J., \& Moag, J. S. (1986). Interactional justice; communication criteria of fairness. In R. J. Lewicki, B. H. Sheppard, \& B. H. Bazerman (Eds.), Research on negotiation in organisations (Vol. 1, pp. 43-55). Greenwich, CT: JAI Press.

Bilgin, N. \& Demirer, H. (2012). The examination of the relationship among organisational support, affective commitment and job satisfaction of hotel employees. Procedia-Social and Behavioural Sciences, 51, 470-473.

Bishop, J. W., Scott, K. D., Goldsby, M. G., \& Cropanzano, R. (2005). A construct validity study of commitment and perceived support variables: A multifoci approach across different team environments. Group and Organization Management, 30(2), 153-180.

Blau, P. M. (1964). Exchange and power in social life. New York: John Wiley.

Caesens, G., Marique, G., \& Stinglhamber, F. (2014). The relationship between perceived organisational support and affective commitment: More than reciprocity, it is also a question of organisational identification. Journal of Personnel Psychology, 13(4), 167173.

Chen, D. J. Q., \& Su-Yen, W. (2016). ASEAN and the AEC: Challenges and opportunities for human resource management. In A. Nankervis, C. Rowley \& N. M. Salleh (Eds.), Asia pacific human resource management and organisational effectiveness (pp. 17-37). Greenwich, CT: JAI Press.

Chin, W. W. (2010). How to write up and report PLS analyses. Springer. 
Choong, Y. O., Tan, L. P., \& Choe, K. L. (2014). Supervisory support, organisational justice and perceived organisational support: A review and research agenda. Information Management and Business Review, 6(5), 255-260.

Cohen, J. (1988). Statistical power analysis for the behavioural sciences. (2nd ed.). Hillsdale, New Jersey: Lawrence Erlbaum Associates.

Cropanzano, R., \& Mitchell, M. (2005). Social exchange theory: An interdisciplinary review. Journal of Management, 31(6), 874-900.

Cropanzano, R., Prehar, C. A., \& Chen, P. Y. (2002). Using social exchange theory to distinguish procedural from interactional justice. Group \& Organisation Management, 27(3), 324351.

Dawley, D. D., Andrews, M. C., \& Bucklew, N. S. (2008). Mentoring, supervisory support, and perceived organizational support: what matters most? Leadership \& Organizational Development Journal, 29(3), 235-247.

Ding, C. G., \& Shen, C. K. (2017). Perceived organizational support, participation in decision making, and perceived insider status for contract workers: A case study. Management Decision, 55(2), 413-426.

Eisenberger, R., Huntington, R., Hutchison, S., \& Sowa, D. (1986). Perceived organizational support. Journal of Applied Psychology, 71(3), 500-507.

Eisenberger, R., Stinglhamber, F., Vandenberghe, C., Sucharski, I. L., \& Rhoades, L. (2002). Perceived organizational support: Contributions to perceived organizational support and employee retention. Journal of Applied Psychology, 87(3), 565-573.

Green, S. B. (1991). How many subjects does it take to do a regression analysis? Multivariate Behavioral Research, 26(3), 499-510.

Greenberg, J. (1990). Looking fair versus being fair: Management impressions of organisational justice. In B. M. Staw \& L. L. Cummings (Eds.), Research in Organisational Behaviour and Development (Vol. 12, pp. 111-127). Greenwich, CT: JAI Press.

Gouldner, A. W. (1960). The norm of reciprocity: A preliminary statement. American Sociological Review, 25(2), 161-78.

Hair, J. F., Hult, G. T. M., Ringle, C. M., \& Sarstedt, M. (2017). A primer on partial least squares structural equation modeling (PLS-SEM). ( $2^{\text {nd }}$ ed.). Thousand Oaks, CA: Sage.

Hair, J. F. J., Sarstedt, M., Hopkins, L., \& Kuppelwieser, V. G. (2014). Partial least squares structural equation modeling (PLS-SEM). An emerging tool in business research. European Business Review, 26(2), 106-121.

Henseler, J., Ringle, C. M., \& Sinkovics, R. R. (2009). The use of partial least squares path modeling in international marketing. In R.R. Sinkovics \& P.N. Ghauri (Eds.), Advances in international marketing (Vol. 20, pp. 277-320). Bingley, UK: Emerald.

Jais, J., \& Mohamad, M. (2017). Perceived organizational support and perceived supervisory support as predictors of organizational commitment of Malaysian academics. Journal of Computational and Theoretical Nanoscience, 23(9), 8732-8736.

Konovsky, M. A. (2000). Understanding procedural justice and its impact on business organizations. Journal of Management, 26(3), 489-511.

Lee, O. C., Yusof, A., Geok, S. K., \& Omar, Z. (2017). Examining the relationship between organizational justice and organizational commitment with perceived organizational support of Malaysian high performance school sports development programme (SPTS) volunteer coaches. International Journal of Academic Research in Business and Social Sciences, 7(S), 588-613. 
Lee, J., \& Peccei. R. (2007). Perceived organizational support and affective commitment: The mediating role of organization-based self-esteem in the context of job insecurity. Journal of Organizational Behavior, 28(6), 661-685

Levinson, H. (1965). Reciprocation: The relationship between man and organization. Administrative Science Quarterly, 9(4), 370-390.

Lew, T. Y. (2009). Perceived organizational support: Linking human resource management practices with affective organizational commitment, professional commitment and turnover intention. The Journal of International Management, 4(2), 104-115.

Madden, L., Mathias, B. D., \& Madden, T. M. (2015). In good company: The impact of perceived organizational support and positive relationships at work on turnover intentions. Management Research Review, 38(3), 242-263.

Marique, G., Stinglhamber, F., Desmette, D., Caesens, G., \& Zanet, F. D. (2012). The relationship between perceived organizational support and affective commitment: A social identity perspective. Groups and Organisation Management, 38(1), 68-100.

Mitchell, M., Cropanzano, R., \& Quisenberry, D. M. (2012). Social exchange theory, exchange resources, and interpersonal relationship: A modest resolution of theoretical differences. Handbook of Social Resource Theory, Springer New York Heidelberg Dordrecht London.

Niehoff, B. P., \& Moorman, R. H. (1993). Justice as a mediator of relationship between methods of monitoring and organizational citizenship behaviour. Academy of Management, 36(3), 527-559.

Price. J. L., \& Mueller, C. W. (1986). Handbook of organizational measurement. Marshfield. MA: Pittman.

Purang, P. (2011). Organisational justice and affective commitment: The mediating role of perceived organisational support. Asian Academy of Management Journal, 16(1), 141156.

Ramli, A. A., Salahudin, S. N., Zainol, Z., \& Suandi, T. (2014). Turnover intention among academics: A case study of private higher learning education in Klang Valley. Pertanika Journal of Social Sciences and Humanities, 22(1), 321-334.

Rathakrishnan, T., Imm, N. S., \& Kok, T. K. (2016). Turnover intentions of lecturers in private universities in Malaysia. Pertanika Journal of Social Sciences and Humanities, 24(S), 129-146.

Rhoades, L., \& Eisenberger, R. (2002). Perceived organizational support: A review of the literature. Journal of Applied Psychology, 87(4), 698-714.

Rhoades, L., Eisenberger, R., \& Armeli, S. (2001). Affective commitment to the organization: The contribution of perceived organizational support. Journal of Applied Psychology, 86(5), 825-836.

Shapiro, D. L., Buttner, E. H., \& Barry, B. (1994). Explanations: What factors enhance their perceived adequacy? Organisational Behaviour and Human Decision Processes, 58(3), 346-368.

Shore, L. M. \& Shore, T. H. (1995). Perceived organizational support and organizational justice. In R. Cropanzano \& K. M. Kacmar (Eds.), Organizational politics, justice, and support: managing social climate at work. (pp. 149-164). Wesport, CT: Quorum Press.

Shore, L. M., \& Tetrick, L. E. (1991). A construct validity study of the survey of perceived organizational support. Journal of Applied Psychology, 76(5), 637-643. 
Stinglhamber, F., Marique, G., Caesens, G., Hanin, D., \& Zanet, F. D. (2015). The influence of transformational leadership on followers' affective commitment: The role of perceived organizational support and supervisor's organizational embodiment. Career Development International, 20(6), 583-603.

Wahat, N. W. A., Nasir, R., \& Omar, F. (2009). Intelligent work adjustment approaches of new academics. European Journal of Social Science, 4(7), 7-16.

Yang, F., \& Zhang, L. H. (2012). Organizational justice and perceived organizational support: The Moderating role of Conscientiousness in China. Nankai Business Review International, $3(2), 145-166$. 